\title{
THE ENVIRONMENT COMPONENT IN SUSTAINABILITY ASSESSMENT AT THE LOCAL LEVEL PLAN ${ }^{1}$
}

\author{
Abdul Hadi Harman Shah ${ }^{2}$ \\ Centre of Social, Development and Environmental Studies \\ Faculty of Social Sciences and Humanities \\ UNIVERSITY KEBANGSAAN MALAYSIA \\ Shaharudin Idrus \& Abdul Samad Hadi \\ Institute for Environment and Development (LESTARI) \\ UNIVERSITY KEBANGSAAN MALAYSIA
}

\begin{abstract}
This article discusses the needs and a possible methodology for assessing the environmental sustainability of local plan. Taking local needs and data available into consideration, using Kuala Selangor District as a hypothetical example, the possibility is explored and visualised spatially. Institutional efforts at sustainability indicators development are also highlighted, beginning with questioning our goals and objectives for development and environmental sustainability to select meaningful indicators.
\end{abstract}

Keywords: Environment, Local Plan, Sustainability, Ecological Footprint

\section{INTRODUCTION}

How does one assess the potential impacts of ideas and hopes? Local plans are manifestations of ideas and hopes for better urban living. Today, more than 80 percent of Selangor's populations are currently in urban centers. It is within these urban areas that high proportions of resources including energy are consumed directly by households, and industries for the manufacturing of goods, and waste generation and gas emissions are concentrated. These urban places are the centers of command and control appropriate to their level over

\footnotetext{
1 The earlier version of this paper has been presented at "Bengkel Pengenalan dan Kefahaman Penilaian Kelestarian Dalam Penyediaan Kajian Rancangan Tempatan" organised by Bahagian Rancangan Pembangunan, Pejabat Projek Kuala Lumpur, JPBD Semenanjung Malaysia at Sunway Logoon Resort, Bandar Sunway, Selangor on $4^{\text {th }}$ and $5^{\text {th }}$ October 2004.

${ }^{2} \mathrm{He}$ can be contact at aharmans@pkrisc.cc.ukm.my.
} 
their respective hinterlands. National and state urban policies and plans, official rules and regulations on land development; including buildings, normally have a central cole in any national strategy which promotes sustainable development. Cities and municipal councils are themselves important in that strategy. In the context of the present task it is highly appropriate to assess on what was useful and what was not, what was appropriate and what was less appropriate and so on concerning models and forecasts embodied in all the available plans, in particular the local plans, the subject of this scrutiny.

\section{SUSTAINABILITY SCIENCE AND SUSTAINABILITY GOVERNANCE}

Simply put sustainability science concerns with the scientific studies of sustainable development. Embedded in the term are studies on the various sectors with respect to the environment and the development. Both the physical environment and the human components involving the social, cultural and economic aspects, together with the inter-relation between man and the environment need to be systematically investigated in the context of sustainable development. The scientific studies yield knowledge about the integrity, vulnerability and resilience of both the physical and human components of the environment. Driving forces and the process of economic development, the process of environmental change in the face of socio-economic development, and the impacts of that change are also of major concern. With new understanding and knowledge about the man and environment relationship we can derive indicators and tools for sustainability assessment.

The scientific studies and tools above will not produce the conditions for sustainable development without better efforts at administering the knowledge and tools. At this juncture the scientific study of governance is important to find the best ways to get all sections of society involved in the process of achieving sustainable development. Sustainability governance involves all the institutions - such as government agencies and stakeholders; tools such as regulations, standards, and the entire process in decision making. Central to all these is the achievement of the core shared value that is sustainable development.

\section{Sustainable Development and the 'Environment' Component}

For more than two decades the term 'sustainable development' has been the buzzword worldwide. It is useful to add that the term has attracted too numerous a definition and has set debates to grasp its true meaning. The most widely quoted definition goes: 
'We must meet the needs of the present generation without compromising the ability of future generations to meet their own needs' (WCED, 1987)

The Selangor Sustainable Development Strategy, "Strategi Pembangunan Mampan Selangor" (2000) also adopted this definition, but, of course, with elaborations appropriate to the conditions and development goals of Selangor. More importantly, the term has two main ideas about the management of human activities; one centers on development goals, the other on limiting the harmful impacts of human activities on the environment. The concern for both development and environment has a long history but the question on how the relationship between the two should be articulated is recent. For Malaysia, development goals are a priority, that by 2020 the country would have developed from third world to first. While working towards realizing development goals, the environment should remain in good form, with negative impacts of human actions well in control.

\section{'Environment' Component in Sustainable Development}

When viewing development and environment together, there seems to be some uncertainty as to what is to be sustained. First, is it ecological, socio-cultural or economic that has to be 'sustainable'? Second, shall we focus on national, regional, and local projects or cities?

For the present purpose, the discussion is about the 'environmental component' at the scale of the local plan. Since the concern is more on the environment, for a long while the term 'sustainable' has been widely used in relation to ecological sustainability. In the ecological sustainability the main focus is on natural resources used either in specific projects or the wider programmes of human activities. The assumption is that economic development is necessary to create wealth for socio-economic development and hence improving the citizen's quality of life. Natural resources are necessary to economic development but there are limits to their supply. In this sense development should proceed but always at a rate that can assure sustainable use of resources. Uncontrolled use of resources may result in environmental degradation, resulting in the following:

- Reduction in the quantity and quality of resources available for further consumption and production.

- Overuse of the waste-absorbing capacity of the environment.

- Loss in biodiversity. 
- Declining environmental resilience resulting in increased incidence of hazards.

- Increasing pressure on land for future built-up environment.

In the process of development activities that are seen to be sustainable, this ecological component should meet the following characteristics, namely;

- The activities do not damage natural resources overtly.

- The overall effects of development have negative effects on certain resources but carry positive impacts on others.

Components of sustainable development has been disaggregated (Hardoy, Mitlin and Satterthwaite, 1992:181) into the following: - sustainable use of renewable resources (such as fresh waters, aquifers, soil, biomass); maintaining within absorptive capacity of local and global sinks for waste (such as for greenhouse gases, ozone depleting, chemicals, surface run-off keeping within BOD of water bodies); minimizing use of non-renewal resources (fossil fuels, minerals and loss of biodiversity); and meeting human needs involving access to natural resources, access to adequate healthy environment and basic services.

The scope allows for a search of assessment indicators that have some commonalities across larger areas and specific indicators that are unique to the local scene.

\section{SUSTAINABILITY ASSESSMENT: ENVIRONMENTAL SUSTAINABILITY}

Sustainability assessment is essential to ensure that all efforts towards achieving the shared value of sustainable development are on course. Since 'development' entails the interactions of many sectors, we need to pay attention to the impacting sectors that range from institutions and their policies on development to the developers themselves. The impacts on the environment are varied, some more noticeable than others.

\section{Environmental Assessment of Development Plans}

There is an increasing body of literature examining environmental assessment of development plans lately. This environmental assessment of development should be distinguished from that of an EIA (Environmental Impact Assessment). One group of study asserts that such an assessment is commonly 
referred to as 'strategic environmental appraisal' (Tyldesley and Associates, 2003). The group maintains that the assessment is a process of identifying and assessing the effects of a development plan on the environment. The group suggests that assessment may be taken into account before a development plan is approved. However, it is interesting to note that in making the assessment, the plan's objectives, policies and proposals must be seen in relation to the larger environmental objectives of the country. It also identifies possible impacts. This is done through constant assessment and adjustment such that the plan will produce minimal impacts on the environment.

\section{Assessing the Environmental Sustainability Assessment of a Local Plan}

In the context of the current discussion the assessment is different from the more established Environmental Impact Assessment (EIA) that is normally carried out for certain size projects before the actual project is carried out. The assessment is made on the existing state of the environment before project development. Although there has been request for continual monitoring and post-project assessment, the EIA is basically about the current conditions of the environment and it is a reaction to a specific development proposal.

The environmental aspect of sustainability assessment of a local plan is a process. It goes through the cycle of plan preparation, implementation, monitoring and review. If a local plan is already available the assessment of the environment should follow through the cycle. It is able to deal with wider considerations such as providing some strategic locational problems. It helps to unravel cumulative impacts of several development proposals especially those that are too small for any EIA. In short, the sustainability assessment of the environment in a local plan can assess overall environmental impacts of implementing a plan.

\section{Potential Benefits of Assessing Environmental Sustainability of Local Plans}

There are potential benefits in doing the assessment. Among them is the clarification of environmental aims and objectives of the local plan, and to see if there is any conflict between the local plan environmental objectives and the wider environmental objectives of the planning authority. Sustainability assessment also allows the local government to look into consequences of policies and development proposals on the environment, looking at all possible measures to minimize or prevent the impacts of development on the environment and guiding development activities to be in line with the environmental aims of sustainable development. 


\section{DERIVING A METHODOLOGY FOR SUSTAINABILITY ASSESSMENT}

While the structure plan is a strategic planning document to present, conceptually, long term development strategies, the local plan is where'these ideas are made site-specific, even to the land parcels level. While the structure plan presents broad policies and a general demarcation, it is at the local plan that these ideas are made more concrete. Assessing sustainability at the local plan level, thus, is not merely the evaluation of the current environment; it is also an evaluation of on-going planning efforts at sustaining the environment, and the continued drive towards sustainable development.
What do we assess?

1. Assessing the environment

a. Assessing the characteristics of the environment

i. Vulnerability

ii. Resilience

b. Assessing the quality of the environment

2. Assessing the local plan

a. Impacts of planned change

3. Assessing projects

a. Assessing feasibility

b. Assessing effectiveness

Figure 1: What do we assess?

There are several aspects of sustainable assessment necessary at the local plan level. The first is an assessment of environmental characteristics which should be used to determine the vulnerability and resilience of the local environment. Next an assessment of impacts from the changes proposed in the local plan should be done. Only when both assessments are completed can one assess the current and future quality of the environment, signifying its level of sustainability and livability.

Aside from the planning level, local plans are referenced for any development projects proposed. Environmental sustainability assessment of these projects can assist in determining the contribution or hindrance that the project would have on the continued sustainability of the environment. Assessment of environmental feasibility and effectiveness are often part of the exercise

\section{Methods of Assessment}

Assessment is an exercise in detailed reasoning. To assess fairly one needs

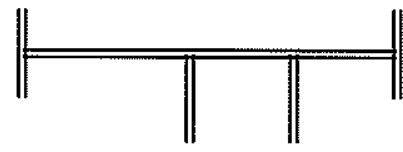

Descriptive Analytic Evaluative Optative

Figure 2: Assessment within the environmental analysis continuum 
to realise that any assessment is value-laden. The important part is to ensure that the values be made explicit. Defining goals and objectives is part of the explication process. To ensure that the assessment process is relevant to the local experience, the values that the goals and objectives are meant to represent must be made clear. To simply transplant global goals without a local context would make the goals meaningless. The local context can be set in the constraints to be identified next. These are local conditions that set realizable targets to goals and objectives. Local conditions often require an inventory of the environment as well as changes expected. Interventions either in terms of development plans, new industries or infrastructures are then evaluated, focusing on their impacts. These impacts are then converted to indicators of sustainability, standardized and presented for decision taking.

Some examples of common tools for sustainability assessment include:

1. Ecological footprint

2. Environmental Sustainability Index

3. Wellbeing Index

4. Environmental Pressure Index

\section{Ecological footprint}

A favorite tool in assessing environmental sustainability is the ecological footprint analysis. Ecological Footprint (EF) is an accounting tool to measure environmental impact through the calculation of area needed to support activities in a sustainable way. It 'estimates the resource consumption and waste assimilation requirements of a defined human population or economy in terms of corresponding productive land area 'Wackernagel and Rees 1996).

\section{Environmental Sustainability Index}

Environmental Sustainability Index (ESI) attempts to measure the progress towards sustainability of nations by using a variety of indicators, which represents the most important factors determining the sustainability (Global
1. Defining Goals and Objectives

2. Defining local constraints

3 . Inventorying state of the environment

4. Identifying changes

5. Identifying interventions

6. Identifying impacts

7. Converting impacts into indicators of sustainability

8. Presenting sustainability

Figure 3: General Steps in Assessment 
Leaders et al, 2002). ESI is an index that is achieved by aggregating 68 indicators, which are divided into five core components:

- Environmental Systems

- Reducing Stress

- Reducing Human Vulnerability

- Social and Institutional Capacity

- Global Stewardship

\section{Wellbeing Index of nations}

Wellbeing index (WI) is a sustainability assessment method for human communities in global, national or local level. It considers human society and nature as equal systems, and gives them equal weight. The icon, Egg of Wellbeing, is used to illustrate sustainability where white is being the ecosystem that surrounds the humans symbolised with the yolk (Prescott-Allen, 2001).

While these tools are commonly used to assess sustainability, they require data collection and management that are not usually available to the local authorities. With efforts and commitments all local authorities can develop their own environmental footprint and indices of sustainability mentioned. One can even develop a sustainability analysis of the structure and local plans but perhaps a more customised or preliminary assessment given current conditions is more pertinent at the beginning of the assessment exercise.

\section{LESTARI'S EFFORTS AT SUSTAINABILITY INDICATOR DEVELOPMENT}

At the local scene, the Institute for Environment and Development (LESTARI) at Universiti Kebangsaan Malaysia (UKM) has been active in the development as well as the construction of sustainability indicators. Focusing on indicators for developing countries, several of the studies pointed towards a methodology for appropriate sustainability indicators. Peterson, P.J. et al. (1997a) began the effort with indicators at the national level, linking these indicators to those available globally. LESTARI then moved to look at indicators for urban and the industries. Today LESTARI is embarking on yet another stream of need; assessment of sustainability at the local level, and linking that to the need of development plans, especially at the local plan level. Yet all with one purpose the development of a better understanding of sustainability. A few studies have been carried out at Institute for Environment and Development (LESTARI), 
Universiti Kebangsaan Malaysia (UKM) regarding the sustainability indicator development especially in Malaysia. The discussion of the sustainability indicators development touching on concept of indicators and application to the various levels of government agencies (see Peterson, P.J. 1997a; Peterson P.J. 1997b; Nordin M. 1999; Nordin M. 20001a; Nordin M. 20001b; Peterson P.J. 2000a; Peterson P.J. 2000b; Peterson P.J. 2002a; Peterson P.J. 2002b; Peterson P.J. \& Granados 2002; Peterson P.J., Sham Sani \& Nordin, M. 1999; Peterson, P.J., Ahmad Fariz Mohamed \& Mazlin Mokhtar 2003; Sham Sani 2001; A. Latiff et. al. 2004)

\section{Proposed Components of Local Environmental Sustainability Assessment: Compliance, Balance and Goals Achievement}

There are many ways to assess environmental sustainability at the local plan level. All of them require some assumptions. The method proposed in this section is based on several considerations:

- That the local authorities already have a vision of the environmental sustainability to be found in their structure plans and detailed in the local plans. Compliance with the structure and local plans are argued to be in line with promoting environmental sustainability. The question lies in the translation of compliance into sustainability indicators.

- That the local community can define environmental sustainability goals.

- That balance between user and producer, as well as between sectors are important in determining environmental sustainability.

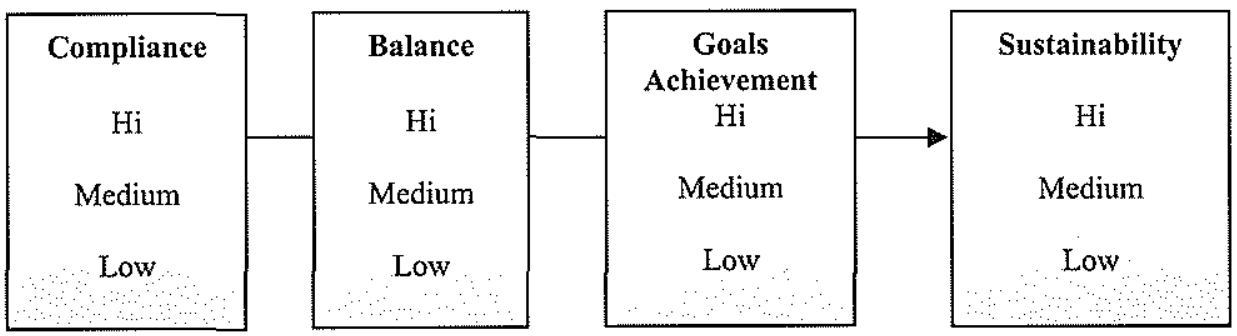

Figure 4: The components of local ESA.

\section{Approach}

The approach combines three common evaluation tools in planning; the checklist method, the goal achievement matrix and the planning balance sheet approach. 


\section{Steps:}

1. Develop a checklist based on environmental related items in the local plan. Determine the extent of compliance to the checklist (Table 1). Begin by determining generally high, medium or low level of compliance. Less than $30 \%$ compliance would be considered low while compliance within $30 \%-70 \%$ is considered medium compliance. Anything more than $70 \%$ would then be considered high. This is of course a simple demarcation to begin the analysis. The checklist method allows one to assess the environment and development activities with respect to predetermined goals and visions.

2. The second part of the analysis requires a re-look at the various environmental, socio-economic and institutional initiatives or policies and to assess them with respect to a few environmental sustainability goals (Table 1). The idea is to determine the extent to which each initiative has achieved the goals set. The local government needs to come together to determine the goals and measures of achievement. For the beginning, the common sectoral objectives for water, air, biodiversity and vector borne diseases can be used to assess achievement.

3. The third step is to place these initiatives as well as samples of specific projects in terms of environmental costs and benefits. The costs and benefits need not necessarily be set within a Ringgit function but to assess equity, producers and users are best determined and separately assessed.

4. The fourth step is to develop a synthesis matrix based on the three previous analyses and present the findings spatially. 


\section{Environmental sustainability of Kuala Selangor: An example in method}

Table 1: Environmental Goals Achievement Matrix

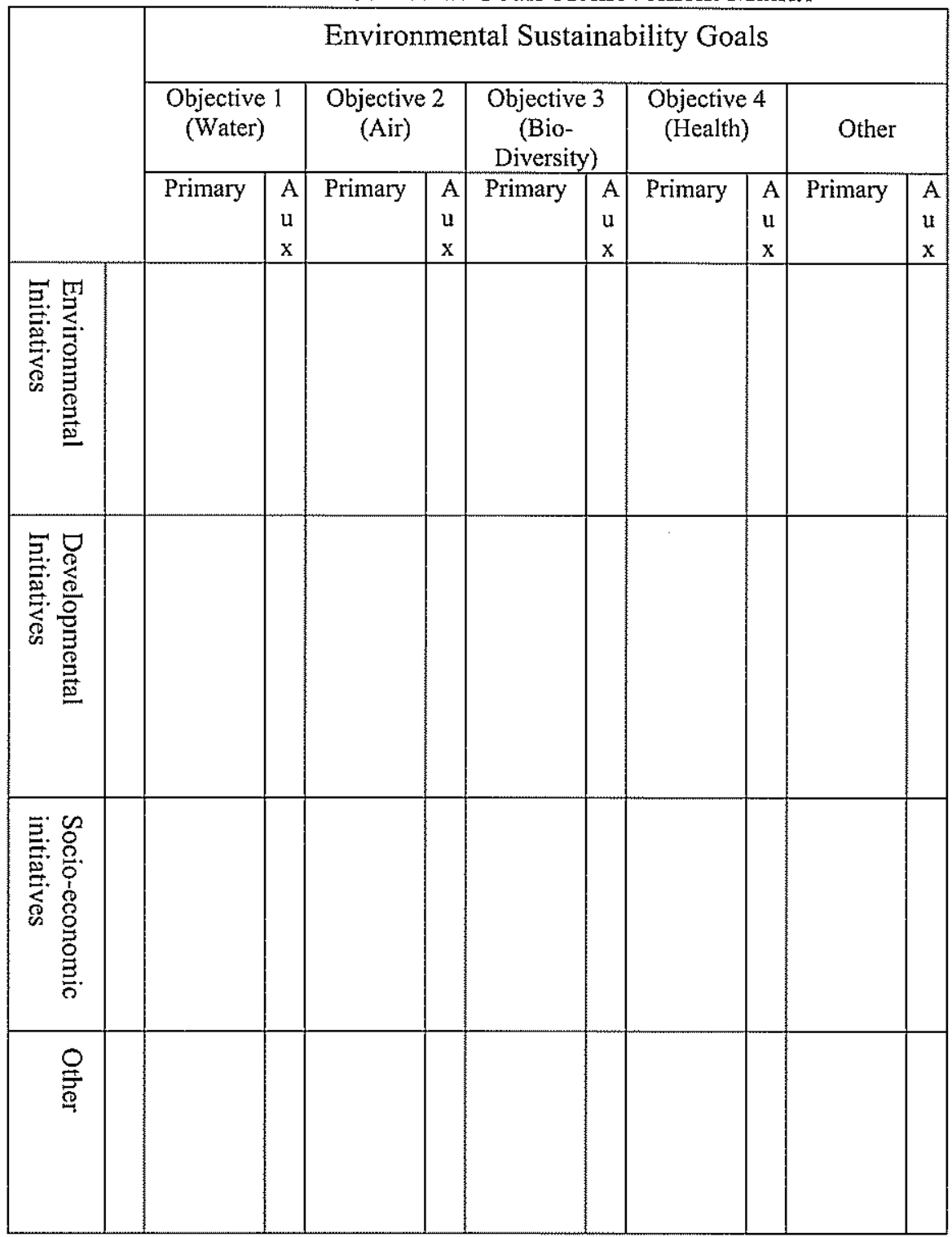


Table 2: Environmental Sustainability Balance Sheet

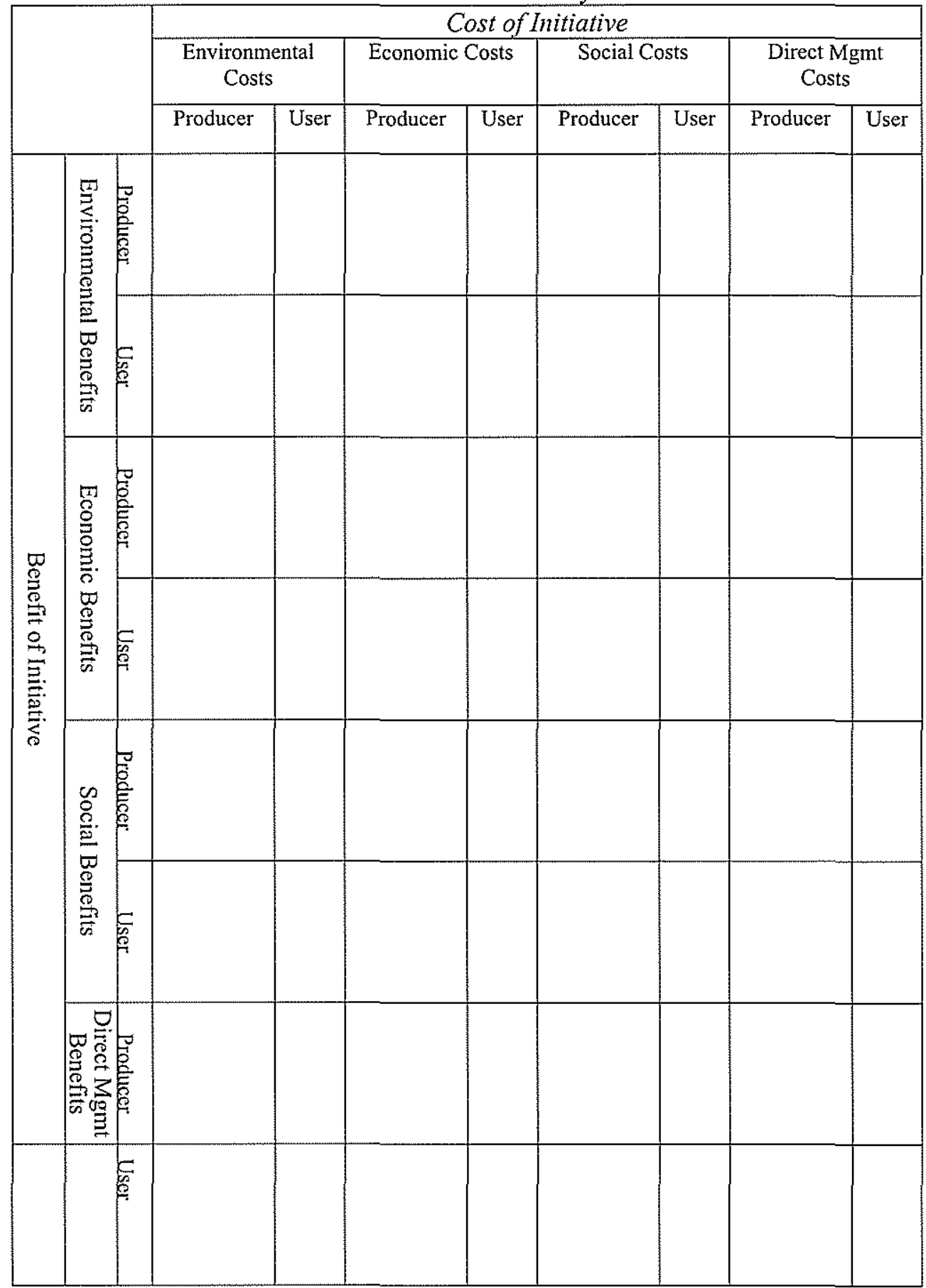


Table 3: Compliance Checklist

\begin{tabular}{|l|l|l|l|l|l|}
\hline \multirow{2}{*}{$\begin{array}{c}\text { Environmental } \\
\text { elements }\end{array}$} & \multicolumn{5}{|c|}{ Compliance Zones } \\
\cline { 2 - 6 } & Housing & Commercial & Industrial & Institutional & $\begin{array}{c}\text { Open } \\
\text { space } \\
\text { and } \\
\text { Access }\end{array}$ \\
\hline Water & & & & & \\
\hline Air & & & & & \\
\hline Noise & & & & & \\
\hline Soil & & & & & \\
\hline Topography & & & & & \\
\hline Slope & & & & & \\
\hline Etc. & & & & & \\
\hline
\end{tabular}

\section{A Truncated Spatial Example}

A hypothetical example of the method, using Kuala Selangor as the case in point, is presented to show possible implementation of the approach. Kuala Selangor's need to maintain the sustainability and richness of its natural environment, both for the ecosystem and economic reasons provides a good example of complementary economic and environmental goals, as well as the need to assess the environment in a more integrated manner.

Matching two elements from Table 1; the development initiative in terms of desired population density, derived from proposed housing density requirements of the local plan, and an emergent environmental element of vulnerability (in this case using the Selangor Environmentally Sensitive Area Classification (KSAS) presents a partial assessment of the local plan. A simple overlay exercise provides a preliminary (level 1) view of where the local plan impacts would be least sustainable, environmentally. Further overlays with other initiative dimensions, as well as detailing specific environmental goals will 
further provide a more integrated assessment of the local plan. Adding weights to the different goals will further fine-tune the assessment model.

Figure 5 summarizes the results of the spatial distribution of environmental vulnerability of Kuala Selangor derived from the matrix in Table 1.

Environmental Vulnerability:

Kuala Selangor

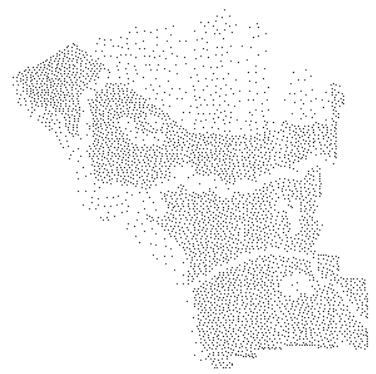

Levels of Env. Vulnerability Low Vulnerablity Medium Vulnerabillty High Vulnerabillty
Population Density: Kuala Selangor

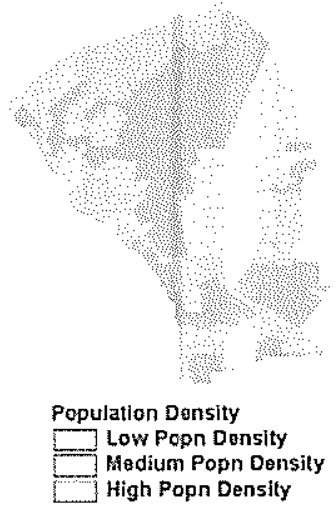

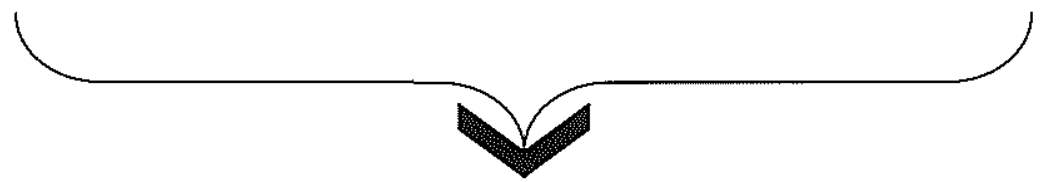

Low Environmental Sustainability Areas

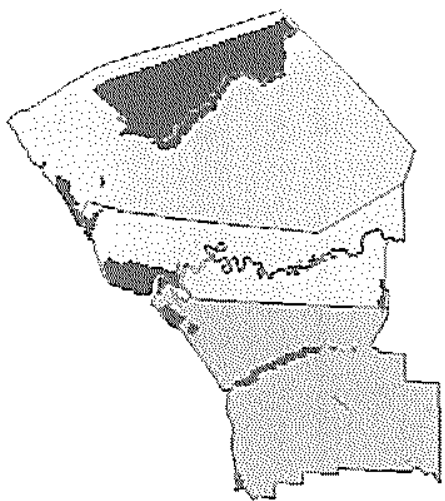

Sustalnatlity Level

[xis Low Sustainability

Developanse zone

Tourism Developant tros

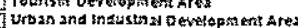

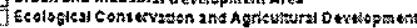

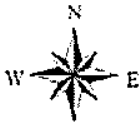

Figure 5: Environmental Vulnerability Index, Kuala Selangor, 2004. 


\section{CONCLUSIONS}

What we wish for in setting up this environmental sustainability assessment method is a better indication of where we are going as a community, given our goals and our base environment. Development plans are often multi-objective, and at times we might lose track of our targets. Part of the effort to develop a better quality of life and increasing the livability of our surroundings, is developing the understanding about the environmental livability of our lives and our dreams for the future. That is also the current global agenda on sustainable development. The problem is on the definition and boundaries of environmental sustainability. It would be easiest to simply pluck ready-made indicators of sustainability put forth by the United Nations and other bodies, made readily available through the net.

Or one can take the more difficult, but more meaningful task of thinking through our own sustainability indicators at the local level. Beginning with questioning our goals and objectives for development and environmental sustainability, we move to select indicators most meaningful in the local context. With these we re-examine our policies and plans, and in doing so we 
re-assess our relationship with our immediate and extended environments; redefining our relationship with our past and future.

\section{REFERENCES}

A. Latiff J.J. Pereira, A. Hezri Adnan, \& A.A. Aldrie. 2004. Indicators of Sustainable Development: Assessing Changes in Environmental Conditions. Bangi: LESTARI Publisher.

Global Leaders for Tomorrow World Economic Forum, Center for International Earth Science Information Network Columbia University (CIESIN), Yale Center for Environmental Law and Policy (YCELP) (2002) 2002 Environmental Sustainability Index. [Online]. Available: http://www.ciesin.org/indicators/ESI/ESI2002 21MAR02a.pdf $\quad[2003$, October 3]

Hardoy, J.E., Mitlin. D. and Satterthwaite, D. 1992. Environmental Problems in Third World Cities. London: Earthscan Publications Ltd.

Lichfield, N. et al. 1975. Evaluation in the Planning Process. New York: Pergamon Press.

Nordin M. 1999. Potential Indicators for Inclusion as Sustainable Development Indicators (SDIs) for Malaysia. Bangi: LESTARI Publisher.

Nordin M. 20001a. Sustainable Development Indicators: Current Status and Future Challenges. In A. Latiff, J.J. Pereira, A.A. Hezri (Ed.). Penyelidikan

Penunjuk Pembangunan Mampan di Universiti Kebangsaan Malaysia.

Bangi: LESTARI Publisher.

Nordin M. 20001b. Indicators of Sustainable Development: the Malaysian

Perspective. In J.J. Pereira \& I. Komoo (Eds) Geoindicators for Sustainable Development. Round Table Dialogue No.7. Bangi: LESTARI Publisher.

Peterson, P.J. 1997a. Indicators of Sustainable Development in Industrializing Countries. Vol. I. Management Response Strategies. Bangi: LESTARI Publisher.

Peterson, P.J. 1997b. Indicators of Sustainable Development in Industrializing

Countries. Vol. II. From Concepts to Action. Bangi: LESTARI Publisher Peterson, P.J. 2000a. Indicators of Sustainable Development in Industrializing Countries. Vol. IV. Second Generation Indicators. Bangi: LESTARI Publisher

Peterson, P.J. 2000b. Indicators for Hazardous Waste Management: National Capacities and Capabilites. In Proceedings Pacific Basin Conference on Hazardous Waste, 10-14 April. Manila. 
Peterson, P.J. 2002a. Sustainable Development Indicators: Concept and Application. In Agenda 21 Selangor Round Table Dialogue: Sustainable

Development Indicators. 23 May. Putrajaya (CD Copy).

Peterson, P.J. 2002b. Performance Indicators for Hazard evaluation of Landfill

Sites. In Proceedings Second Asia-Pacific Landfill Symposium, 25-28

September. Seoul.

Peterson, P.J. \& Granados, A. 2002. Towards Sets of Hazardous Waste Indicators: Essential Tools for Modern Industrial Management. Environmental Science and Pollution Research 9, 204-214.

Peterson, P.J., Sham Sani \& Nordin, M. 1999. Indicators of Sustainable Development in Industrializing Countries. Vol.III. Key Indicators for Tropical Cities. Bangi: LESTARI Publisher.

Peterson, P.J., Ahmad Fariz Mohamed \& Mazlin Mokhtar 2003. Indicators of Sustainable Development in Industrializing Countries. Vol. V. Measuring Industrial Change in Malaysia: Linking Strategies with National Policies.

Bangi: LESTARI Publisher.

Prescott-Allen, Robert (2001) The Wellbeing of Nations: A Country-by Country Index of Quality of Life and the Environment. Washington: Island Press

Selangor. 2000. Strategi Pembangunan Mampan Selangor. (Selangor

Sustainable Development Strategy) Bangi: LESTARI Publisher.

Sham Sani 2001. Developing Urban Sustainability Indicators for Malaysia.

LESTARI Public Lecture Series.No. 3. Bangi: LESTARI Publisher.

Tyldesley, D. \& Associates. 2003. Environmental Assessment o Development Plans. Scottish Executive Social Research. Interim Planning Advice.

Wackernagel, M and Rees, W. 1996. Our Ecological Footprint: Reducing Human Impact on the Earth. Gabriola Island: New Society Publishers WCED 1987. Our Common Future. London: Oxford University Press. 
